\title{
MIGRANT SUFIS AND SHRINES: A MICROCOSM OF ISLAM INTHE TRIBAL STRUCTURE OF MIANWALI DISTRICT
}

\author{
Saadia Sumbal \\ Asst. Prof. Forman Christian College University Lahore, Pakistan, saadia.sumbal@yahoo.com
}

\begin{abstract}
This paper discusses the relationship between sufis and local tribal and kinship structures in the last half of eighteenth century to the end of nineteenth century Mianwali, a district in the south-west of Punjab. The study shows how tribal identities and local forms of religious organizations were closely associated. Attention is paid to the conditions in society which grounded the power of sufi and shrine in heterodox beliefs regarding saint's ability of intercession between man and God. Sufi's role as mediator between tribes is discussed in the context of changed social and economic structures. Their role as mediator was essentially depended on their genealogical link with the migrants. This shows how tribal genealogy was given precedence over religiously based meta-genealogy of the sufi-order. The focus is also on politics shaped by ideology of British imperial state which created sufis as intermediary rural elite. The intrusion of state power in sufi institutions through land grants brought sufis into more formal relations with the government as well as the general population. The state patronage reinforced their social authority and personal wealth and became invested with the authority of colonial state. Using hagiographical sources, factors which integrated pir and disciples in a spiritual bond are also discussed. This relationship is discussed in two main contexts, one the hyper-corporeality of pir, which includes his power and ability to move through time and space and multilocate himself to protect his disciples. The other is through dreams and visions, as an important aspect of Muslim religiosity.
\end{abstract}

Keywords: Mianwali, Sufism, Islamic Reformism, Khanqah, Shrine, Colonial

\section{INTRODUCTION}

I argue in this paper that shrine-based Islam (Sufism) is historically grounded in Mianwali District. Sufism in South Asia has its roots in a socio-cultural context, where hierarchical distinctions between human beings and authority of sufi brotherhoods have largely been established and retained (Lindohlm,Werbner,1988, p.209). In embodying the sacred as a lived reality, the living sufis created and extended new sufi brotherhoods (tariqa), strengthened cults and made tombs as focus of devotees(Werbner,Basu,1988,P.3). Practice and belief appear closely intertwined, grounded in ethical premises. Rituals are practiced not as a result of strong belief but are embodied and ethical.

To understand the place of Islamic institutions in rural Punjab, it is important to look at their origin from historical perspective. This will show how tribal identities and local forms of religious organizations were closely associated (Gilmartin, 1988, P.40). Islam proliferated in Western Punjab due to the services of great 
sufi mystics of the Delhi sultanate period - Baba Fariduddin Ganj-i-Shakar of Pakpattan, Sheikh Bahawal Haq Zakariyya of Multan, Syed Jalaludin Bukhari of Uch and others. The construction of sufi khanqahs and later sufi tombs, emerged as symbolic cultural outposts of the power of Islam and of the Muslim state in a society where local tribal identities remained important. Scholars like Richard Eaton, David Gilmartin, Hans Harder and Clifford Geertz argue that Islam in South Asia is shaped by indigenous culture and so it is hybrid in nature. Against this argument, Orientalists and social scientists of $20^{\text {th }} \mathrm{C}$, including A. J. Arberry working on Muslim societies remarked that Islamic reform spread in South Asia from nineteenth century, opposing some aspects of Sufism (visiting, praying at graves, saintly intercession),alienated a large number of South Asian Muslims from cults, and relegated to backward rural folk (Lindohlm,p.225). Hoffman contested such arguments and maintained that sufi orders were not socially marginal, rather they constituted an important but quietist arena in the lives of people (Bruinessen, Howell, 2003.p.29). Richard Eaton also maintained that interaction with and embeddedness within particular sub-cultures of South Asia was such that Islam had become as Indian as any other religious tradition of Sub-Continent (Eaton, 2003, p.27). Spencer Trimingham also comments "Indian Islam seems to have been essentially a holyman's Islam". For the local population, the holy man represents moral authority (Werbner,p.188). It was shrine which made Islam accessible to nonlettered masses through rituals, providing them a sense of social security and collective identity (Eaton,p. 334). As Gilmartin indicates and as my study amply bears out that the focus on sufi orders, piri-muridi bonds, urs, organization of Khanqah and shrine reflected not only historical structure of Islam in western Punjab but cultural pressure arising from rural society (Gilmartin,p.19). Punjabi Muslim society is viewed by Geertz as "cultural system".(Geertz,1973,p.89) He maintains "Religion was not merely an ideology, but a system of symbols, ideas and institutions which acted to "synthesize" a people's ethos, the tone, and character."(lbid)

I argue that, an important aspect of shrine based Islam, shaped by indigenous culture, has been ignored. Despite the religious controversy and polemical debates between Islamic reformism and Sufism, reformists could not dominate the debate but had to negotiate with the sufis and tried to bring scriptural arguments in consonance with sufi practices.(Werbner,p.67) Reformist ideas could only gained foothold if they are closely tailored with sufistic practices.

\subsection{Methodology}

To explain the historically rooted shrine-based Islam, I draw theoretical insight from Pierre Bourdieu's "theory of society". I use his concept of Habitus, Field and Cultural Capital to understand religious change and reproduction of power relations between religious denominations in society. Habitus is structured by conditions of existence and generates practices, beliefs and perceptions in accordance with its own structure.(Bourdieu,1990,p.39) Habitus is a new sociological gaze to see social world. I consider historically developed shrine based religiosity as a product of habitus. Saint and shrine cults took shape under certain cultural and sociological environment, in which saints responded to people in socio-economic crisis. Beliefs in saint and shrine cults generated certain kind of practices, which were internalized as permanent disposition over the period of time. Bourdieu through habitus, field and capital tried to explain the relationship between people's practices and the contexts in which those practices occur.

Mianwali (Gazeteer, 1990) was geographically and historically a significant part of Cis-Indus territory. The social structure of the society of Mianwali is essentially tribal as it is put in a local parlance. Its normative code and ethics, centrality of patriarchal supremacy, the concept of honour, land-based economic interests, a strong sense of tribal identity are the distinctive features of society of Mianwali. Economic interests and ethnic prejudices had fostered inter-tribal rivalries and stunted mutual harmony and social cohesion.(Sumbal,2008,p.28)

Mianwali constituted what might be termed the "baraka belt" (Smith,1994,p.33). The physical and cultural topography of Mianwali is shaped by saintly remains. The tombs and saint veneration created hierarchies of sacred space with economic and political implications as well as spiritual, moral and emotional contents. Islam in Mianwali was popularized and sustained by the sufi /saints and Islamization was achieved as a result of constant interaction between carriers of Islam, pre-existing religious beliefs and local environment. An ordinary Muslim's understanding of Islam was mediated through the agency of a sufi/ pir. In the context of mass illiteracy, poverty and socio-economic issues, the tombs of the saint became sites of special access to religious power. (Gilmartin,p.42)

Spiritual factors cannot totally explain the increased strength of sufis and shrine-based Islam. The rise of sufis to prominence stemmed from particular political and socio-religious conditions in which Islamization had to be achieved with the help of local forces. It was closely related to the social and economic structure which was changed as various pathan tribes continued to pour in and gradually settled in Mianwali on the eastern fringe of Indus.(Gazeteer,p.24) Continuous influx of Pathan tribes exacerbated the issues of settlement on 
land and its ownership. These saintly figures tried to resolve the issues by not only providing religious leadership and guidance but also mediated between tribes and carried out non-religious social and economic functions as well.

\section{SUFIS AS MEDIATORS BETWEEN TRIBES}

Mianwali's encounter with Islam grew in the time of Mian Ali, a sufi, member of Qadria order who migrated from Baghdad in 16thC (1584).(Lepel,Messy,Charles,1909,p.58).He introduced an all-inclusive approach which became the local face of Islam and earned him popularity and large following. He followed ascetic practices of Zikr and Chilla and established tremendous influence among people through his miracles (karamat). (Gazeteer,p.18). Two traditions of Islamic devotionalism developed during this time. One was the tradition of mystical endeavour of strongly ascetic nature practiced by them. The second tradition was more popularly oriented. They handed out tawidh or amulets to the common masses who saw in these amulets, a protection against evil, a boon for good fortune or an agent for the cure of an illness.(Eaton,p.265) Mianas giving of amulets and the devotees giving of futuh (gifts) provided the structural framework upon which the subsequent devotionalism of the shrine rested. In the religious sense, the tawidh-futuh system defined and sustained Miana's intermediary status between the devotees and God, as a conduit through whose intercession with God, one's wishes may be fulfilled. (Ibid) These sufis received social recognition once their barakas were transmitted to people and benefitted them. Distribution of Baraka in society was fundamental to the construction of saintly persona and conferring him a special and sacred niche within the social order. (Smith,p.34)

These sufis also acted as mediators, had a kinship relation with those tribes. They developed an enduring link between themselves and Pathan tribes. Frederik Barth and Akbar.S.Ahmed suggested that sufis who were outsiders to the Pakhtun jirga-style political assemblies, asserted no power there, as they were not part of the tribal genealogy, except in a situation where the tribe had to seize power in the absence of 'traditional' Maliki authority (Ahmed, 2013). Sana Haroon's work "Frontier of Faith" also shows the mullah acted as tribal mediator, was culturally engaged with Pakhtun society and a participant of Pakhtun Wali (the unwritten cultural code of Pukhtun tribes men).(Haroon, 2011, p.68)These conclusions may be applied to Mianwali where only those sufis mediated between tribes who were having their genealogical link with them. This showed that Saints were classified according to their affiliation with tribal genealogy, which was given precedence over religiously based meta-genealogy of the sufi order.(Ibid) Here I want to mention that Mianas were outside the tribal structure of Mianwali, yet they mediated between tribes. The reason was not just the spiritual factor or the religious sanctity of Mianas but the relationship was also inspired by opportunistic motives of creating political and economic hegemony over other tribes by using support and religious influence of these saintly figures.(Shah, p.67) Settlement and possession of land among too many hostile tribes was a constant challenge for them.(Kazmi, p.65) Nile Green mentioned in his work on Afghan sufis that they created a network of affiliation which contested the formation of communities on the basis of kinship. This helped Afghans to adjust themselves in Indian culture. (Green,2008) Such was not the case in Mianwali. Here the problem was to maintain the distinctive Pathan identity, which came under the combined threat of affiliation to a multiethnic land and the experience of diaspora life at large. Pathan tribes settled in Mianwali with economic ties to the land, therefore economic distractions turned out to be more powerful than the drive for collective Pathan identity.(Ibid) Attempts to acquire fertile lands by the 'have-nots' at the expense of the 'haves' created a situation of 'perpetual conflict' in which sufi could play a valuable mediating role. (Ansari, 1992, p.26)

\subsection{Militarization of Sufi's Authority}

In this relationship of mutual assistance between sufis and disciples, the sufi tried to martial his disciple tribes to fight for political and economic interests (Haroon, p.85). For the development of religious politics, lashkar was used as the most instrumental element in the enforcement of their political directives. (Ibid) Militarization of a sufi's authority was crucially linked to the militarization of the tribal area's population in general. The sufis's raising of a lashkar signified his access to and recognition by different tribes which formed the foundation of his religious authority. (Ibid) The militant mobilization and convening of lashkar were actually rooted in tribal issues of occupation of land and water, honour and pride. The underlying reason for such militarized actions was rooted in Pathan cultural codes of defence and pride and the use of force to protect a tribe's position.(Ibid) Hence 'Islamic inclinations and Pathan culture' came together in the management of issues. Cultural concern with the defence of honour is underlying all the issues.(Ibid)

The process of Islamization in Mianwali followed patterns experienced across India, but it was influenced by circumstances and conditions peculiar to the region itself. The marginal status of Mianwali in political and economic terms created conditions in which the institution of the sufi/pir flourished. 
Mianwali became formally a part of British Empire with the annexation of Punjab in 1849. The British needed the support of the native society in social and political development. The British constructed a system of political control by preserving the landed interests of local elites including religious elites. Their help was crucial in maintaining order and resolving disputes between tribes. (Pasha, 1998, p.163)

Politics in twentieth-century Punjab was shaped by the principles and ideology that had defined the British imperial state and created a class of an intermediary rural elite.(Gilmartin, 1984, p.39)The tomb of sufis became a site of special access to religious power that was transmitted through spiritual charisma or barakat to saint's tombs and to their living descendants.(Eaton, 1978, p.204) The exercise of mediation by these descendants of saint emerged as a dominant style of mediatory religious leadership in rural Punjab. (Gilmartin, p.42)

The transformation of dargah into a permanent feature of the Punjabi landscape permitted and created a relation between sufi and the local population. With this there was a spectacular growth of popular cult focused on shrine. We find two dimensions of this growing cult:

1) The extension of mass devotionalism into the countryside. 2) Patronage of shrines and sufis by the Colonial State. (Eaton, 2003, p.267)

\section{MIANAS AS MEDIATOR BETWEEN COLONIAL STATE AND PEOPLE}

In the absence of a strong well-defined state framework, sufis formed the central pillar in the structure of local political authority. The individual, spiritual and temporal influence of these Qadri sufis played a crucial role in constructing the system of collaboration and land grants. In return for 'collaboration', sufis were rewarded with grants of land and other honours, thus greatly increasing the temporal power they wielded.

One important reason for the growing relations with religious people was the local pressures the British faced. The British encountered considerable challenges from Pathan tribes and the support of these sufis was crucial in establishing a well-developed framework. Miana sufis rendered valuable assistance in settling blood feuds and land disputes which had until then cost many lives annually.(Lepel, Messy, Charles, p.296) In return they got Charitable grants, and important designations in colonial administration. One of the important elements of British patronage was the public distribution of izzat, which demonstrated status; the central aspect was award of a chair at the darbar. The grant of this privilege signalled the recognition of the institution of sajjada nishin and his local identity.(Ansari, 1992, p.48)

The intrusion of state power in sufi institutions through land grants brought sufis into a new relationship with each other as well as with the state and the general population. The state patronage of Mianas reinforced their social authority and personal wealth and became invested with the authority of colonial state. The substance of religious authority extended beyond the pedagogic and divine intercessionary mandate of sufi tariqa and became linked to temporal power.(Haroon, p.38) These holy men were associated with, in Nile Green's terms, aetiological legends, concerning the founding of villages and water sources. (Green, 2008) They created the local landscape of Mianwali, its wells, springs, settlements, mosques. In the absence of state, sufi provided support, It was in this context that a strong pir-murid relationship was established.

\section{PIR-MURID RELATIONSHIP}

The Pir and Murid relationship was strictly hierarchical, tied the murid up in an extensive set of rules which on one level, prevented closeness and on another level created intimacy between the two. Disederio Pinto explained in his article on Nizamuddin's dargah, the pilgrims believed that it was the sufi master who made them acceptable to God since he was concerned about their problems and so interceded on their behalf. (Pinto, 1989, p.10) In the lives of unprivileged, marginalized groups such as peasantry, shrine emerged as an alternative source of identity which acted as therapeutic institution, curing physical sickness, lack of progeny as well as resolved social, political and economic problems.(Malik, p.189)These shrines can be regarded as 'microcosm of local Islam'. The therapeutic structure provided by this organization turned out to be effective due to the culturally patterned expectations of disciples in distress.

\subsection{Karamat (Miracles), As Sufi Way of Communication}

The most visible expression of baraka was the ability to perform karamat (miracles) which signalled a temporary suspension of natural order of things through divine intervention. Saints with their abilities to perform miracles, needed to give them sense of security against the daily uncertainties of life.(Libieskind, 1998, p.226) 
The sensory functions and limbs of disciple are subject to his will. This strength and power of sufi master make them appear as "hyper corporeal". The sufi spread himself through time and space in order to protect multitudes of disciples (murids) (Bashir, 2011, p.187). The master also had the ability to be present in multiple locations at the same time. This power to multilocate reflected the breath of influence of master. His power to move through time and space showed that sufi master's body is free of limitations and restrictions which are usually placed on ordinary human bodies.

\subsubsection{Dreams as sufi way of communication}

Another important sufi way of communication was through dreams and visions. The Prophet (PBUH) received the earliest message of Islam in a vision in which beginning of Islam was announced. The Quran in this sense may be seen as a visionary text. Hence visions assumed vital significance in Sufism. (Green, 2003) Recounting of dreams and visions was an important aspect of Muslim religiosity. Through dreams the sufi master and his disciple developed a relationship and a sense of closeness. Dreams allowed the disciples to be looked after while away. Such a close interaction through dream took place only with key disciples. The dead saint in his tomb was no less a continuing source of power and help. His shrine became a physical heir of his Baraka, turned out to be a fount of spiritual power to his disciples. The sufi's moving out of his grave indicated that his long range abilities and hyper-corporeality survived even after his death.(Liebiskind, p.92)

This is instructive to note that some of the sufis espoused strict puritanical traditions, having initiation in Naqshbandia sufi order, and yet there was a fusion of shariat and tariqat in their khanqah. At the same time reformist ideas through Abdullah Chakralwi's AhlulQuran and Hussain Ali's Deobandi movements had reached Mianwali till the middle of nineteenth century, which strongly contested the sufi practices including intercession of saints and celebration of Urs. Reformist ulema called them innovation against religion. They emphasized centrality of Tauheed, the transcended unity of God. Concerns of religious knowledge, identity and practices dominated the discourses and conflict between Sufism and reformist Islam emerged as the dominant theme of twentieth century in colonial Mianwali. Despite attacks of reformist ulema, the sufi-disciple relationship remained strong.

\section{CONCLUSION}

In the absence of a state or well developed administrative framework, sufi masters had long acted as peace brokers in local quarrels and tribal feuds or as intermediaries between the tribes and later among community and the colonial officials. Sainthood was continually proven by the display of power. The topographic presence of the shrines of the sufi saints and their continued miraculous intervention in the lives of their communities made them inevitable. Ordinary people turned to sufi master in times of crisis, who provided social support and counseling, which may be defined as assistance and protection in tangible terms through financial aid and through intangible terms such as emotional support. Sufi's humanitarian and modernization work earned them devotees. Mediation and brokerage based upon spiritual and moral authority over religious clienteles gradually eroded and diverted to other purposes, much to the benefit of colonial regime. With this piety among Miana sufis, the leading clerics of nineteenth century gradually started to decline. To preserve their sinking religious authority, they were forced to develop religious ties with Chishti Sufis of Sial Sharif, a strong sufi order in Punjab's countryside. Reformists also launched attacks against sufic practices and called them non-Islamic practices towards the last decade of nineteenth century. The practices like zikr, chilla, the Urs ceremony and the popularity of shrines as religious institution in Mianwali, defies the view of many scholars of South Asia that the two-century-long rise of Islamic reformism turned the saintly shrines and sufic practice as redundant and receding traditional mode of religious orientation. Most of the shrines espoused a syncretic tradition of shariat and tariqat and contested those reformist ideas which criticized some aspects of Sufism. Shrine-based Islam which came to be viewed as marginal, managed to assert its perspective on Islam vis-à-vis pressure from reformist ulema.

\section{REFERENCE LIST}

Ahmed, A. S. (2013). Islam in Tribal Societies: from the Atlas to the Indus (Vol. 18): Routledge.

Ansari, S. F. (1992). Sufi Saints and State Power: The Pirs of Sind, 1843-1947. New York: Cambridge University Press.

Arberry, A. J. (1950). Sufism: An Account of the Mystics of Islam (Vol. 2). London: George Allen \& Unwin.

Barth, F. (1965). Political Leadership among Swat Pathans. London: Athlone Press.

Bashir, S. (2011). Sufi Bodies: Religion and Society in Medieval Islam. New York: Columbia University 
Press.

Bourdieu, P. (1977). Outline of a Theory of Practice (Vol. 16). New York: Cambridge University Press.

Bourdieu, P. (1990). The Logic of Practice. Stanford, Calif.: Stanford University Press.

Bruinessen, M. v. (2003). "Sufism and the 'Modern' in Islam". ISIM Newsletter, 13, 1.

Clancy-Smith, J. A. (1994). Rebel and Saint: Muslim Notables, Populist Protest, Colonial Encounters (Algeria and Tunisia, 1800-1904) (Vol. 18). Berkley: University of California Press.

Dupree, L. (1973). Afghanistan. Princeton, N.J.: Princeton University Press.

Eaton, R. M. (1978). Sufis of Bijapur, 1300-1700: Social Roles of Sufis in Medieval India. Princeton, N.J.: Princeton University Press.

Eaton, R. M. (2003). India's Islamic Traditions, 711-1750. New Delhi: Oxford University Press.

Eickelman, D. F. (1989). The Middle East: An Anthropological Approach. Englewood Cliffs, N.J.: PrenticeHall.

Geertz, C. (1973). The Interpretation of Cultures: Selected Essays. New York: Basic Books.

Gellner, E. (1969). Saints of the Atlas. Chicago: University of Chicago Press.

Gilmartin, D. (1988). Empire and Islam: Punjab and the Making of Pakistan. London: I. B. Tauris \& Co.

Green, N. (2003). "Migrant Sufis and Sacred Space in South Asian Islam". Contemporary South Asia, 12(4), 493-509.

Green, N. (2003). "The Religious and Cultural Roles of Dreams and Visions in Islam". Journal of the Royal Asiatic Society of Great Britain \& Ireland, 13(03), 287-313.

Green, N. (2004). "Stories of Saints and Sultans: Re-Membering History at the Sufi Shrines of Aurangabad". Modern Asian Studies, 38(02), 419-446.

Green, N. (2008). "Tribe, Diaspora, and Sainthood in Afghan History". Journal of Asian Studies-Ann Arbor-, 67(1), 171.

Green, N. (2011). Bombay Islam: The Religious Economy of the West Indian Ocean, 1840-1915. New York: Cambridge University Press.

Green, N. (2012). Sufism: A Global History (Vol. 34). MA: John Wiley \& Sons.

Griffin, L. H., Massy, C. F., Conran, W. L., \& Craik, H. D. (1909). Chiefs and Families of Note in the Punjab. Lahore: Printed at the Civil and military gazette Press.

Harder, H. (2011). Sufism and Saint Veneration in Contemporary Bangladesh: The Maijbhandaris of Chittagong. Abingdon, Oxon; New York, NY: Routledge, Taylor \&Francis.

Haroon, S. (2011). Frontier of Faith: Islam, in the Indo-Afghan Borderland. London: Hurst Publishers.

Hoffman, V. J. (1995). Sufism, Mystics, and Saints in Modern Egypt. Columbia, S.C.: University of South Carolina Press.

Katz, J. G. (1996). Dreams, Sufism, and Sainthood: The Visionary Career of Muhammad Al-Zawâî (Vol. 71): Brill.

Kazmi, Shah, Masood. Tariq (2001). Sarzameen-e-Aulia Mianwali. District Mianwali Publishers.

Liebeskind, C. (1998). Piety on its Knees. Three Sufi Traditions in South Asia. Delhi: Oxford University Press.

Metcalf, B. D. (1984). Islamic Revival in British India: Deoband, 1860-1900: Princeton: Princeton University Press.

Mianwali, District. (1915), Gazetteer. Lahore, Sang-e-Meel Publishers.

Nanda, B. N., \& Talib, M. (1989). Soul of the Soulless: An Analysis of Pir-Murid Relationships in Sufi Discourse. Muslim shrines in India. New York: Oxford University Press.

O'Brien, A. (1911). "The Mohammedan Saints of the Western Punjab". The Journal of the Royal Anthropological Institute of Great Britain and Ireland, 41, 509-520. 
Pasha, M. K. (1998). Colonial Political Economy: Recruitment and Underdevelopment in the Punjab. Karachi: Oxford University Press, USA.

Pinto, D. (1989). The Mystery of the Nizamuddin Dargah: The Accounts of Pilgrims. Muslim Shrines in India: Their Character, History and Significance. Delhi: Oxford University Press.

Robinson, F. (1983). "Islam and Muslim Society in South Asia". Contributions to Indian Sociology, 17(2), 185203.

Robinson, F. (2008). "Islamic Reform and Modernities in South Asia". Modern Asian Studies, 42(2-3), 259281.

Rozehnal, R. (2007). Islamic Sufism Unbound: Politics and Piety in Twenty-First Century. Pakistan: Pelgrave, Macmillan.

Sumbal, Saadia, (2008). Tribal Configuration of Mianwali: A study in Colonial Dispensation, (Unpublished MPhil thesis).

Shah, Alamgir (1999). Malfuzaat Maratib-e-Sultani. District Mianwali Publishers.

Troll, C. W., \& Gaborieau, M. (2003). Muslim Shrines in India: Their Character, History and Significance. New Delhi: Oxford University Press.

Werbner, P., \& Basu, H. (1998). Embodying Charisma: Modernity, Locality, and Performance of Emotion in Sufi Cults. Psychology Press. 